\title{
Epicormic resprouting in fire-prone ecosystems
}

\section{J uli G. Pausa $\mathrm{s}^{1,3, *, @ ~ a n d ~ J ~ o n ~ E . ~ K e e l e y ~}{ }^{2}$}

Many plants resprout from basal buds after disturbance, and this is common in shrublands subjected to high-intensity fires. However, resprouting after fire from epicormic (stem) buds is globally far less common. Unlike basal resprouting, post-fire epicormic resprouting is a key plant adaptation for retention of the arborescent skeleton after fire, allowing rapid recovery of the forest or woodland and leading to greater ecosystem resilience under recurrent high-intensity fires. Here we review the biogeography of epicormic resprouting, the mechanisms of protection, the fire regimes where it occurs, and the evolutionary drivers that shaped this trait. We propose that epicormic resprouting is adaptive in ecosystems with high fire frequency and relatively high productivity, at moderate-high fire intensities.

\section{Post-Fire Epicormic Resprouting}

Many plant speciesfrom a wide range of ecosystemsare able to recover their green biomass afterdisturbance by resprouting new shoots[1]. It is often assumed that the higherthe intensity of the disturbance, the lowerthe height at whic h bud sresprout new shoots [2-4]. The consequence is that after a severe disturbance, such asan intense fire, most resprouting speciesresproutfrombudsburied beneath the bark of structuresat the ba se ofthe plantor belowground. Thus, many plantsliving in fire-prone ecosystemsha ve evolved structuresto concentrate buds belowground (e.g., lignotubers, xylo podia, woody rhizomes [5-8]). This has signific ant implic ationsforg rowth form a smost of these are multistemmed shrubs.

However, a number of arborescent speciesstand out from this pattem and resprout from the trunk orbranches in the crown ca nopy even aftera high-intensity fire, a phenomenon termed post-fire epicomic resprouting. Many plants can generate epicomic shoots after light disturbances, but here we refer to those species that resp rout epicomic ally after fire, and especially after crown fires (see G lossa ry). Particularly striking is the fact that forests subjected to similarfire intensities often exhibit striking differenc es with respect to epicormic resp routing. Forexample, the vigorousepic ormic resprouting in the na tive eucalypt forests in Australia contrast with the total lack of resprouting in the dead Pinus radiata plantation right next to the forest despite them experiencing similar fire intensity (personal observations). Similarly, eucalypt plantations in southem Euro pe show vigorous epic omic resprouting afterc rown fires compared with the native broad-leaved trees (basal resprouting) and pines (fire killed) $[9,10]$. Because epic omic resproutersma inta in theirstructure afterfire, the a bility to resproutepicomically has strong implications for the speed of vegetation recovery and carbon balance and in general on ec osystem functioning. Desp ite the importance of this unique fire adaptation, it hasnotbeengloballywelld oc umented and ispoorlyrepresented in planttraitdata bases[11]. In this $O$ pinion artic le we addressthe question of why some tree lineageshave evolved epic ormic resprouting and others have not. To do so, we examine the distribution of epicormic resprouting among plants, the fire regimes where they live, and the evolutiona ry drivers that shaped epicomic resprouting.

\section{Trends}

Whether a tree resprouts from the base or from stem (epicomic) buds hasstrong implic ationsforforest structure and carbon balance in post-fire conditions.

Epic ormic resprouting is a key plant trait that allows quick regeneration of the tree and of ec osystem functioning.

Epicomic resprouting is especially a daptive in ec osystems with high fire frequency and relatively high productivity, at moderate-high fire intensities.

Epic ormic resprouters are the trees most resilient to high-intensityc rown fires.

'CIDE-CSIC, Carretera CV-315, Km 10.7, Montcada, Valencia, Spain ${ }^{2}$ US Geological Survey, Western Ecological Research Center, SequoiaKings Canyon Field Station, Three Rivers, CA 93271, USA

${ }^{3}$ http://www.uv.es/jgpausas/

${ }^{\circledR}$ Twitter: @jgpausas

*Correspondence: juli.g.pausas@ext.uv.es (J.G. Pausas). 


\section{Biogeography}

Perhapsone of the most thoroughly studied cases of epicormic resprouting is in the Australian genus Eucalyptus and the closely related genera Corymbia and Angophora [12,13]. Following high-intensity crown fires in these Eucalyptus forests, the vast majority of trees, regardless of size, resp routepic omic ally (Figure 1). Within lessthan 1yearthese forestsa re wellon their way to recovening their full canopy. However, resprouting is of variable importance in

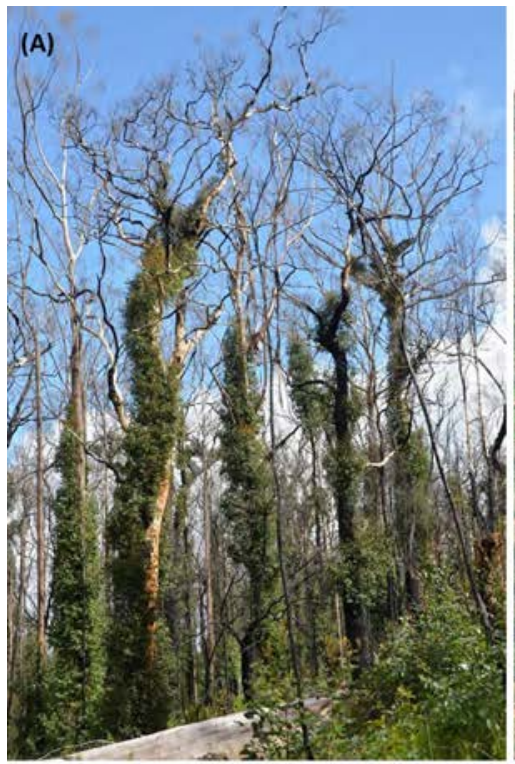

(B)

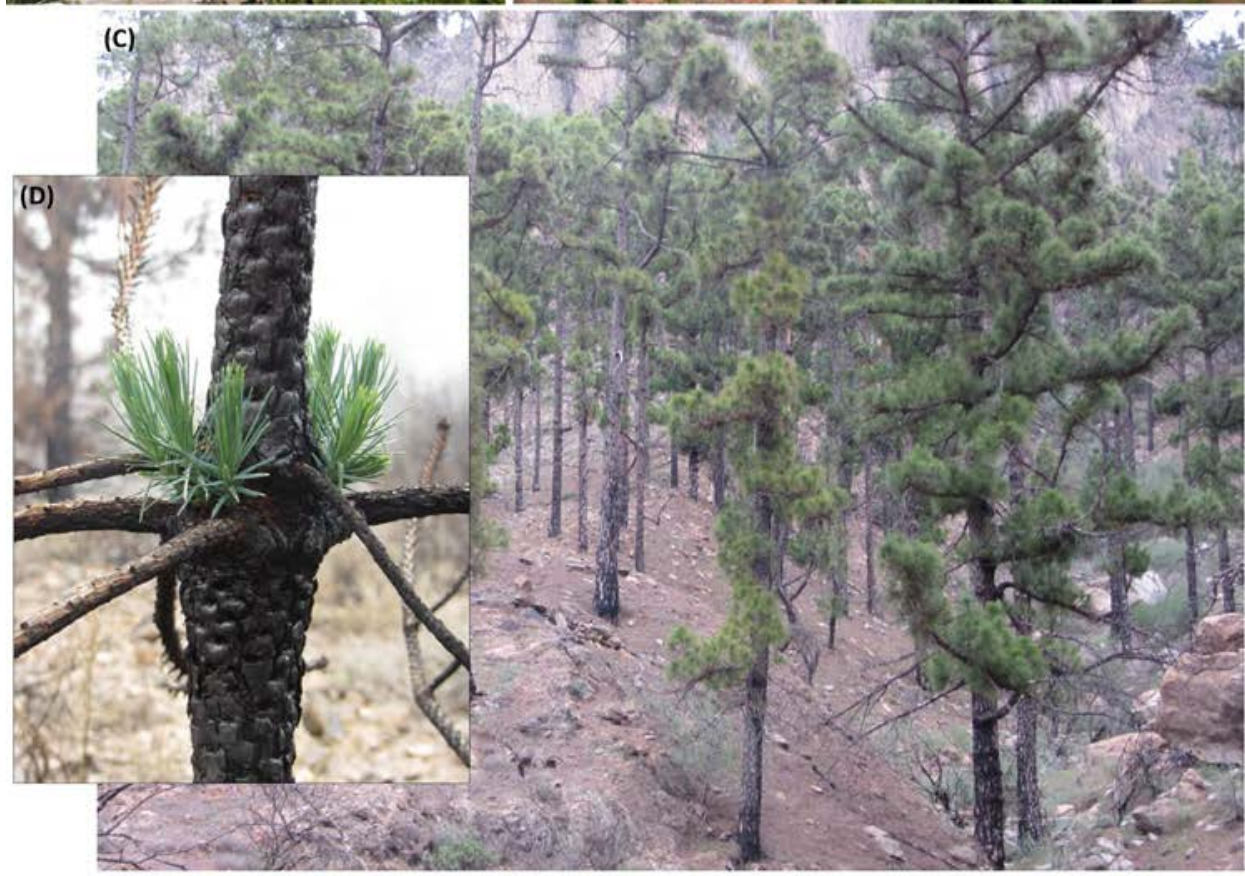

Trends in Plant Science

Figure 1. ExamplesofPost-Fire Epic ormic Resp routing a ftera CrownFire. (A)Eucalyptusdiversicolor 18months afterfire in Westem Australia. (B) Quercus suber woodland 1.5yearspost-fire in southem Portugal. (C) Pinus canariensis woodland a few years afterfire; (D) epic ormic resprouts of $P$. canariensis 3 months post-fire. Photographs by G. WardellJ ohnson (A), F.X.Catry (B), and J.G. Pausas(C,D).

\section{Glossary}

Crown fires: fires in woodydominated vegetation that affect most of the crown of the dominant plants; fire might spread through the crowns (active crown fire) or through surface fuels but torching individual tree crowns (passive crown fires).

The frequency is often lower than in surface fire regimes and thus a vailable fuels are often greater, contributing to more intense fires. We distinguish two types; see below. Fire regime: wildfire characteristics that prevail in a given area; it may vary through time. It is typic ally defined by frequency, intensity, sea sona lity, and types of fuels consumed. Spatial va ria bility leading to differing levels of patchiness may also charactenize the fire regime. Two common and contrasted fire regimes are surface fire regimes and crown fire regimes; mixed fire regimes also occur.

High-intensity crown fires: crown firesthatbuma majorfraction of the twigs and branches (woody-fuelled fires); typic al of Mediterranean and borealec osystems. Theirfrequency istypic a lly lowerthan that of lowintensity crown fires.

Low-intensity crown fires: crown fires that bum (or only scorch) the foliage of the crowns but most woody parts (twigs and branches) are not consumed. They are often passive crown fires and are typical of some tropical and subtropic al forests and woodlands. Because they do not consume woody fuels, they can be more frequent than high-intensity crown fires. A regime of frequent low-intensity c rown firesislikely to select for epic ormic resprouting. Mixed surface-crown fires: surface firesin forestsorwood lands with frequent torching to the crowns generating a mosaic of surface and crown fires. The proportions of surface versus crown fires vary markedlyin both time and space. In manyc oniferousforests, theyare typic ally called mixed-seventy fires, but forthe sake of generality the term should be independent of the effects of fire on the tree (severity). Surface fires: fires that affect surface fuels only; they spread through fine fuels in the herbaceous and litterlayer(grass-fueled fires, litter-fueled fires). They are typical of grasslands, savannas, and woodlands. In forest ecosystems 
Eucalyptus and some have limited capacity for resprouting and are considered post-fire obligate seeders $[14,15]$. There are other trees with post-fire epic ormic resprouting in Australia aswell a sin So uth Afric a (Table 1), including exa mplesthatexhibit within-species(amongpopulation) variability in epicomic and basal resprouting $[16,17]$.

In the northem hemisphere, the genus Quercus also exhibits widespread occurrence of epicormic resprouting after fire (Table 1 and Figure 1 ). This is true only in the arborescent species; all shrubby oaks resprout from the base. Thick-barked arborescent oaksthat resprout epic ormic a lly resproutfrom the base when in a juvenile state (i.e., the ba rkisstill too thin to a llow stem survival) orwhen debarked, a sisthe c a se in corkoak (Quercus suber, debarked due to otherwise non-lethal commercial cork extraction $[18,19])$.

Conifersare distinct in that resprouting isrelatively rare compa red with woody angiospems. A few speciesdo resprout[20-23]; however, they genera lly do notresproutepic ormic a lly afteran intense fire, with a few exceptions. Forinstance, Pseudostuga macrocarpa in the Califo mian chaparral resprouts vigorously afterfire from upperbranches but only when growing on steep slopes where fire intensities are lower; otherwise it dies [24]. Another exception is in the genus Pinus, where the majority of more than 125 species have evolved in close association with fire $[20,25-27]$. Of the few resprouting pines, some are a ble to produce a few epicomic short branchesespecially at the lower part of the bole or when young (e.g., Pinus rigida, Pinus serotina, Pinus patula, Pinus montezumae; [28,29]), although they are often completely killed by crown fires. In some cases, however, theyc an generate epic ormic resproutsafterfiresthat defolia te the tree (e.g.,P. rigida). Pinus canariensis stand souta sa strong post-fire epic ormic resprouterafterhigh-intensity crown fires (Figure 1 and Table 1 ), with a magnitude of resprouting equivalent to that of the euc alypts and cork oak. Resprouting of thisspecies is suc cessful in all treesof any size, from sa plings (with basa I resprouting) to mature trees (with strong epic ormic resprouting). Indeed, Pinus canariensis was used in the past in some reforestation projects in Spa in intermixed with Pinus halepensis; when it bumsin the typical high-intensity crown fires of $P$. halepensis, $P$. canariensis shows quick full crown recovery by epic ormic resp routing (and $P$. halepensis diesand recruitspost-fire from seeds[30]).

Table 1. Selected Specieswith Field Evidence of Ep ic omic Resp routing a fterHigh-Intensity Fires, witha Rough Indic ation of the OuterBark Thic kness in Adult Pla nts ${ }^{a}$

\begin{tabular}{|l|l|l|l|}
\hline Species & Region & Outerbark & Refs \\
\hline Allocasuarina decussata & Australia & Thick & {$[47]$} \\
\hline Banksia attenuata & Australia & Thin & {$[17]$} \\
\hline Banksia menziesii & Australia & Thick & {$[16]$} \\
\hline Corymbia calophylla & Australia & Thick & {$[47]$} \\
\hline Eucalyptus diversicolor & Australia & Thin & {$[47,48]$} \\
\hline Eucalyptus guilfoylei & Australia & Thick & {$[47]$} \\
\hline Eucalyptus marginata & Australia & Thin & {$[47]$} \\
\hline Pinus canariensis & Canary Is. & Thick & {$[49]$} \\
\hline Protea nitida & South Africa & Thick & {$[22]$} \\
\hline Quercus agrifolia & Califomia & Very thick & {$[50]$} \\
\hline Quercus kelloggii & Califomia & Thick & {$[51]$} \\
\hline Quercus suber & Med. Basin & Very thick & {$[18,19]$} \\
\hline
\end{tabular}

${ }^{a}$ This is not an exhaustive list but includes some illustrative examples doc umented in the literature.

${ }^{\mathrm{b}}$ Thin, 1-2 cm; thick, 2-4 cm; very thick, $>4 \mathrm{~cm}$ ). surface fires are often called understory fires and there is a vertic al disc ontinuity of the fuels in such a way that tree crownsa re not affected by the fire. Surface firesare often frequent but of low intensity, but can be of high severity for trees with thin bark (e.g., rainforests). 


\section{Fire Regime}

Many plantscan generate epic ormic shoots after light disturbanc es (e.g., browsing, drought, stand thinning, low-intensity fires, insect defoliation, strong winds [31]) but this does not mean theygenerallyresp route pic ormic allyafterfire, asthe heat of a fire may killepic ormic budsifthey are not well protected (Box 1 ). Post-fire epic ormic resprouting occ ursin so me ec osystems subject to frequent crown fires (forests) as well as those und er frequent surface fires (savannasand open woodlands; Figure 2).

Post-fire epic o mic resprouting iswid espread in sava nnas[32-34], where grass-fuelled fires are frequent and of low intensity. Forinstance, of the 63 speciesstudied in an Afric an savanna [34], 18 species (in eight families) showed stem buds strongly covered by bark, 13 species (ten fa milies) showed no protec tion, and 32 spec ies (17 fa milies) showed intermediate valuesofbud protection. In many of these savannas, epicormic resprouting is especially important for juveniles, where the plant canopy is lower than the flame height of surface fires. Depending on its bud protection, species resprout epic ormic ally orfrom basal buds. In Brazilian sa va nnas (cerrado) with low soil fertility and high rainfall, trees grow slowly, but grasses are tall and juvenilesare una ble to surpassflame heightduring the inter-fire interval; thus, a thic kcorky bark coupled with leavesthat have weak fla mma bility allows young treesto resist fires[33,35,36]. In thissystem the flame height in relation to the tree height ishigh, making thick bark at the top of the branc hesadaptive [37]. Rec urrent firesc onsume only the terminaltwigsand plantsresp rout epic ormic ally loweron the stem, generating the typic al appearance of tortuouscerrado trees [36].

In ecosystems under high-intensity crown fires, epicomic resprouting is globally rare. For instance, associated with Ca lifomian chapa ral is Pseudostuga macrocarpa, a tall tree that resprouts vigorously after fire from upper branches. This species commonly grows in association with chaparral and is often bumed by high-intensity crown fires. Following fire it istypically killed where ithasc olonized into dense c hapa rra land fuelloadsa re high butitsurvivesin refugia on steep slopeswhere fire intensitiesa re lowerand epic ormic resprouting a llowspopula tionsto recover ra pidly [24]. Anotherillustrative example isthe case of Q. suber and Quercus Ilex, which often coexistinforestswith a crown-fire regime in the westem Mediterranean Basin; in such

\section{Box 1. Mechanisms for Bud Protection}

Epic omic resprouting arises from protected buds (or bud-forming cells) in the stem and branches $[12,13,44]$. These latentordomantbuds, typic ally of axillaryorigin, can be ac tivated at any time in response to defoliation (e.g., drought, insects), butif theyare properly protec ted theyc an be ma ssively a c tivated afterd efolia tion by fire. There a re atleasttwo mechanismsby which speciesmay protect these stem budsand bud-forming tissuesfrom the high temperatures of the fire: one isto develop a thick, protective outerbark [37,38]; the otheristo sink the budsdeeply into the innerbarkoreven the outerwood $[12,44]$. In both casesbudsare, to some extent, protected by the bark, but in the lattercase the outer barkmay be relatively thin, asin the case of some Eucalyptus (Ta ble 1). Euc alyptshave multiple strandsof cellsthatcan form budsat vario usdepthswhen they receive the a ppropriate ho monalsignal[13]. A thick, corky barkin the twigsand branchesnotonly protec tsthe bud sbuta lso reduc esfla mma bility [35] and thusreduc esfire intensity and severity. Extremely thick outer bark can engulf buds and reduce resprouting [45], but in some species furrows in the bark and na rrow tubesc onnec ting the bud to the outside of the stem seem to preventobstruction [46].

In many tropic al savannas, where firesare of low intensity (surface fires), there isa range of intermediate situationswith high varia bility in the degree of protection; for exa mple, northem Australia [32] and southem Africa [34], although in South Americ an savanna shaving a thick, corky outerbarkseemsto be the dominantmechanisma llowing bud survival and subsequent epicomic resprouting [33,36].

In some species, despite having bud-forming tissuesand showing an ability to generate some epicomic shoots, postfire epic omic resprouting isweakornil, especially afterhigh-intensity fires; thisisthe case forthe obligate post-fire seederEucalyptus regnans [15]. Thatis, the presence of bud trac esin the wood orepic ormic shootsin the trunkdoes not ensure post-fire epicomic resprouting, even for trees from fire-prone ecosystems. 


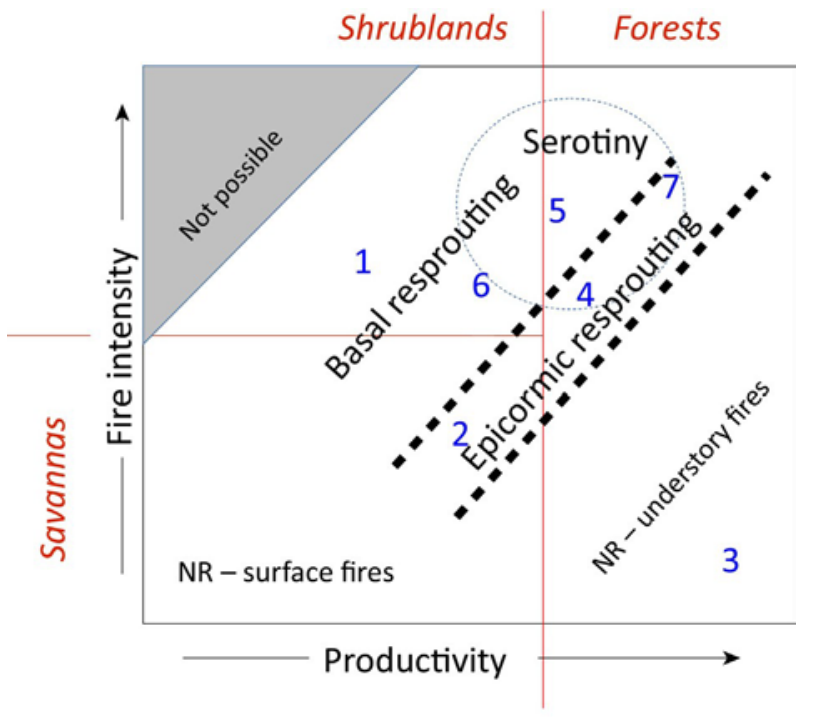

Trends in Plant Science
Figure 2. Schematic Representation of the Occurrence of Post-Fire Epicomic Resprouting, Basal Resprouting, and Serotiny in Relation to Fire Intensity and Site Productivity. In any ecosystem there are often a variety of stra tegies coexisting; here we highlight the ma in strategy for the dominantwoody species. Thisrefers to ecosystems with high natural ignitions (high fire frequency). In thisspace, serotiny (in the circle) and epicomic resprouting (between thick broken lines) often overlap, but they disaggregate in a third dimension (not shown): fire frequency. Serotiny is unlikely when fire intervals are shorterthan the maturity age. Note that low-productivity environments cannot support high-intensity fires (grey area). Red linesare rough limits between forests, shrublands, and savannas, although in fact they can overlap along the productivity gradient. Woodlands (not indic a ted forsimplicity) would be loc ated under high-produc tivity sava nnas and low-productivity forests. 'NR' means conditions where resprouting is of little relevance (weakorabsent) forthe dominant growth form; for example, where fla me height to plant height is low [37], like in forest with frequent understory fires protected by thick basal bark (right) or in some savannas and grasslands (left). Numbers are the approximate locations of some ec osystems: 1, chapa ral-type shrublands; 2, Brazilian savannas; 3 Pinus ponderosa, Pinus palustris; 4 , Pinus rigida, Pinus serotina; 5, Pinus halepensis; 6, mallee-type Eucalyptus; 7, tall Eucalyptus, Pinus canariensis.

high-intensity fires, $Q$. suber ( with thic kerbark) resp routsepic o mic a lly while $Q$. ilex respro uts from the base. However, they also coexist in open woodlands (sa va nnas and dehesas [19]), and if they bum in a crown fire the fire intensity is lowerthan in the forests (low-intensity passive crown fires) and both show epicormic resprouting. Of the species that do resprout epicormic ally afterhigh-intensity (woody fuelled) fire (Table 1), only a few (e.g., Eucalyptus spp., $P$. canariensis, Quercus spp.) are dominant in forest and woodlands of Mediteranean and warm temperate ec osystems, making these ec osystemsstrongly resilient to most fire regimes. In such ecosystems, crown fires are not stand-replacing as in the case of crown fires in the majority of Northem Hemisphere conifer forests.

\section{Evolutionary Drivers}

Ep ic omic resprouting isa daptive in fire-prone ec osystemsbec a use the plant doesnot lose the bulkof woody biomassafterfire, thusenabling the canopy crown to recoverquic kly. Retention of the tree skeleton aftera crown fire has dec ided advantages (e.g., in termsof plant biomass and height aswell as in seed production afterfire) overspeciesthat resprout from the base or regenerate from seeds. So, one c ould a sk why epic ormic resprouting isnotmore frequent. Allocating some carbon to a thic kbarkwould save a large amount of carbon lost in the dead stems. 

We propose thatepic ormic resp routing is a daptive inc erta in cond itions defined ma inly by site produc tivity, fire frequency, and fire intensity (Figure 2). One of the pre requisitesforthisstrategy is site produc tivity suffic ient to susta in an arboresc ent growth form. In open savanna habitats where herbaceousfuels promote frequent low-intensity fires, epicormic resprouting hasclear a dvanta ges by ra pidly reestablishing the canopy crown on the orig inal struc ture. In these lowintensity fires, small increases in bud protection are a daptive. This is especially evident in ec osystems where small plants persist within the flame zone of grass-fuelled firesfor long, as in the Bra zilian savannas(cerra do); in such cases, fire a ctsin a ma nnersimila rto low-intensity crown fires [38] and selectsforepic omic resprouting. A more diffic ult question, however, is why some forest species have evolved epic ormic resprouting and others have not. On low-tomoderate-productivity sites, shrubland specieshave developed the ability to resprout basally after fire and regenera te in entirety their shrub ca nopy c rown (Figure 2). On more productive sites, trees predominate and theirresponse to fire israthermore variable. On highly productive sitessome speciescan esc a pe fire by ma inta ining the tree c anopy hig h a bove surface fuels(e. g., Pinus ponderosa orPinus palustris woodlands; Figure 2); the evolution of thic kbarka round the base of the tree, sometimes coupled with self-pruning of the lowerbranches, issuffic ient to survive these frequent understory fires $[20,27,38]$. However, where produc tivity is more limited treesc annot outgrow surface fires; rather, they are connected by ladderfuelsthat extend into the canopy, and thus treesare subjected to crown fires. Some such specieshave adapted to periodic high-intensity crown fires by evolving serotinous cones that maintain an aerialseed bank that responds to fire by releasing seedsfor abundant post-fire seedling rec nuitment [39]. However, serotiny would be favored only if the mean fire interval were longer than the time required for seedlingsto reach maturity. That is, epic ormic resprouting is a daptive under frequent firesthat affect the crown: (i) if fires are so frequent (in relation to tree maturity) and homogeneousthatserotiny fa ils(immatunity risk; see Box3 in ref[23]); and (ii) in lineagesthat lackstructuressuitable forbecoming serotinous (e.g., oaks). So, epicomic resprouting is likely to be selected for in forestsor woodland swith moderate productivity and high fire frequency where the uppercanopies are scorched from surface firesthat feed on lower branches and a djacent mid-level fuels (passive crown fires). The foliage and sma ll branches from abundant post-fire resprouting along the stem (e.g., in pinesand euc alypts) could act asa ladderfuel to c army the fire to the crown, furtherenhancing crown fires. The fact that some post-fire epic ormic resprouters also have some level of serotiny (some Eucalyptus, $P$. canariensis, and a few Americ an pineslike Pinus leiophyla [21]) emphasizes the existence of so me similaritiesbetween the fire regimesselec ting forthese two tra its(Figure 2) and suggeststhat fire reg imeswith fire intervalsvarying around a value similar to the maturity age could make both traitsadaptive.

In Eucalyptus epic ormic resprouting is an ancient tra it dating back to about $60 \mathrm{Ma}$ [40], when climatic conditionsin Australia were less arid and, coupled with low-nutrient substrates, crown fireswere possibly lessintense than contemporary fires. Such low-intensity crown firescould give the appropriate selec tive environment forthe evolution of bud-protection mechanismsin the stem (Box 1). Then, with increased aridification and seasonality during the Cenozoic [41], fire would have increased in intensity and thusfurtherselected forstrongerbud protection. This quantitative increase in bud protection is not depicted in phylogenetic analyses based on binary data (epicomic resprouter: yes/no [40]). It is also interesting to note that some eucalypt species, despite having some bud traces in the outermost wood (i.e., bud-forming potential), do not resprout epic ormic ally after fire ordo so only wea kly (e.g., Eucalyptus regnans [15]); this is because the bud-forming cells a re the only ones remaining a live and thus the vascular cambium in that area is dead. These species are in a phylogenetic clade of epicomic resprouters and thus seem to be a case of loss of resprouting capacity in favorof the post-fire seeding species [23]. 


\section{Concluding Remarks}

Many plant lineages in environments subjected to predictable fireshave evolved the capacity for resprouting aftersuch disturbance [22,42]. Most emphasishas been placed on whethera species resp routs or not; however, whether a plant resp routs from basal or from upper epic ormic budshasimportant implic ationsforthe speed of regeneration and ecosystem functioning in general. Yetepic omic resprouting ispoorly rec orded in the literature and is absent in most plant trait databases (see Outstanding Questions). Epicormic resprouting can beachieved throughvariousmechanisms(Boxl)and hasa ppeared indifferentlineagesand on different continents, thus, it is a n exa mple of convergent evolution in fire-prone ec osystems. It is likely to be an adaptation to fire and espec ially to a regime of frequent fires that affect tree crowns. Itha sprobablybeenfavored where produc tivityissuffic ientto ma intain a narboresc ent growth form, fire intensity issuffic ient to defoliate the tree canopy crown, and fire frequency is high (in conifers, too high forserotiny to be relia ble). Given the high resilienc e of forest and woodlandsdominated by epic omic resprouters, these speciesare good candidatesfor reforestation in fire-prone ecosystems[19]. Und erstanding post-fire epic o mic resprouting may allow us to better predict ec osystem responses to fire regime changes underscenarios of globalchange and especia llyto betterpredictc arbonbudg ets[43], asthese differdrastic ally betweenba saland epic omic resp routers(see O utstand ing Questions). Overall, more attention should be given to key traitsrelated to disturbance responses, asthey have implic ationsforour understanding of the future of many of our ecosystems.

\section{Acknowledgments}

This Opinion article was prepared under the framework of the FILAS project (CGL2015-64086-P) from the Spanish govemment (Ministerio de Economía y Competitividad) and the FOCSEC project (PROMETEO/2016/021) from the Valencia govemment (Generalitat Valenciana). The authors thank Geoff Burrows, Byron Lamont, Dylan Schwilk, and P. van Mantgen fortheircomments. The CIDE (Desertific ation Research Centre) isa joint institute of the Spanish National Research Council (CSIC), the University of Valencia, and Generalitat Valenciana.

\section{References}

1. Pausas, J .G. etal. (2016) Towardsunderstanding resprouting at the global scale. New Phytol. 209, 945-954

2. Bellingham, P.J . and Sparrow, A.D. (2000) Resprouting asa life history strategy in wood y plantcommunities. Oikos 89, 409-416

3. Bond, W.J . and Midgley, J J . (2001) Ec ology of sprouting in woody plants: the persistence niche. Trends Ecol. Evol. 16, 45-51

4. Klimešová, J . and Klimeš, L (2003) Resprouting of herbs in disturbed habitats: isit a dequately described by BellinghamSparrow's model? Oikos 103, 225-229

5. Maurin, O. et al. (2014) Savanna fire and the origins of the 'underground forests' of Africa. New Phytol. 204, 201-214

6. Paula, S. et al. (2016) Lignotubers in Mediterranean basin plants. Plant Ecol. 217, 661-676

7. Lamont, B.B. et al. (2017) African geoxyles evolved in response to fire; frost came later. Evol. Ecol. Published online May 27, 2017. http://dx.doi.org/10.1007/s10682-017-9905-4

8. Pausas, J.G. etal. (2017) Unearthing belowground bud banksin fire-prone ecosystems. New Phytol. (in press)

9. Catry, F.X. et al. (2006) Effects of fire on tree survival and regeneration in a Mediterranean ec osystem. In 5th International Conference on Forest Fire Research (Viegas, D.X., ed.), Elsevier

10. Paula, S. et al. (2009) Fire-rela ted traits for plant species of the Mediterranean Basin. Ecology 90, 1420-1420

11. Kattge, J. et al. (2011) TRY - a global da tabase of plant traits. Glob. Change Biol. 17, 2905-2935

12. Burrows, G.E. (2002) Epicormic strand structure in Angophora, Eucalyptus and Lophostemon (Myrtaceae) - implications for fire resistance and recovery. New Phytol. 153, 111-131

13. Burrows, G.E. (2013) Buds, bushfires and resprouting in the euca lypts. Aust. J. Bot. 61, 331-349
Nicolle, D. (2006) A classific ation and census of regenerative strategies in the eucalypts (Angophora, Corymbia and Eucalyptus -Myrtaceae), withspecialreference to the obligate seeders. Aust. J. Bot. $54,391-407$

15. Waters, D.A. etal. (2010) Eucalyptus regnans (Myrtaceae): a firesensitive euc a lypt with a resprouterepic ormic structure. Am. J. Bot. 97, 545-556

16. Groom, P. and Lamont, B. (2011) Regionaland localeffectson reproductive allocation in epicomic and lignotuberouspopula tionsof Banksia menziesii. Plant Ecol. 202, 2003-2011

17. He, T. (2014) Ecological divergence and evolutiona ry transition of resprouting types in Banksia attenuata. Ecol. Evol. 4, 3162-3174

18. Pausas, J .G . (1997) Resprouting of Quercus suber in NESpa in afterfire. J. Veg. Sci. 8, 703-706

19. Aronson, J .etal.,eds(2009) Cork OakWoodlands on the Edge Ecology, Adaptive Management, and Restoration, Island Press

20. Keeley, J.E. and Zedler, P.H. (1998) Evolution of life histories in Pinus. In Ecology and Biogeography of Pinus (Richard son, D.M., ed.), pp. 219-250, Ca mbridge University Press

21. Rodríguez-Trejo, D.A. and Fulé, P.Z (2003) Fire ecology of Mexican pinesand fire management proposal. Int. J. Wildland Fire 12 23-37

22. Keeley, J.E. et al. (2012) Fire in Mediterranean Ecosystems: Ecology, Evolution and Management, Cambridge University Press

23. Pausas, J.G. and Keeley, J.E. (2014) Evolutionary ecology of resprouting and seed ing in fire-prone ec osystems. New Phytol. 204, 55-65

24. Keeley, J.E. et al. (2006) South coast bioregion. In Fire in California's Ecosystems (Sugihara, N.G., ed.), pp. 350-390, University of Califomia Press
Outstanding Questions

Can we test the proposed model (Figure 2) with global data? This requires compiling information on epicomic resprouting at the global scale in a standa rdized form and making it available inglobal plant traitdatabases.

How did epicomic resprouting evolve in relation to otherresp routing mechanisms? A phylogenetic approach would bedesirable.

Can we quantify the advantage of epicomic resprouting, for instance using closely related species or populations with different resprouting types?

What is the fire intensity threshold for switching between epicomic and basal resprouting?

How do predictionsofcarbonbalance and ecosystem function improve when epic omic resprouting is included in vegetation dynamics models?

To what extent are epicomic resproutersresilient to any fire regime change?

Can we relate among-population (intraspecific) variability in epicomic resprouting to fire regime variability? 
25. Keeley, J.E. (2012) Ecology and evolution of pine life histories. Ann. For. Sci. 69, 445-453

26. He, T. et al. (2012) Fire-a dapted traits of Pinus arose in the fiery Cretaceous. New Phytol. 194, 751-759

27. Pausas, J.G. (2015) Evolutionary fire ecology: lessons leamed from pines. Trends Plant Sci. 20, 318-324

28. Stone, E. and Stone, M. (1954) Root collarsproutsin pine. J. For. $52,487-491$

29. Gucker, C.L. (2007) Pinus rigida . In Fire Effects Information System. US Department of Agriculture. http://www.fs.fed.us/ database/feis/

30. Pausas, J.G. et al. (2004) Post-fire regeneration varia bility of Pinus halepensis in the eastem Iberian Peninsula. For. Ecol. Manag. 203, 251-259

31. Meier, A.R. et al. (2012) Epic ormic budsin trees: a review of bud esta blishment, developmentand domancyrelease. TreePhysiol. $32,565-584$

32. Burrows, G.E.etal. (2010) A wide diversity of epic ormic structuresispresent in Myrtac ea e speciesin the northem Australian savanna biome: implic ationsforadaptation to fire. Aust. J. Bot. $58,493-507$

33. Dantas, V.L et al. (2013) Fire drivesfunctional thresholdson the savanna-forest transition. Ecology 94, 2454-2463

34. Charles-Dominique, T.etal. (2015) Bud protection: a key traitfor species sorting in a forest-savanna mosaic. New Phytol. 207, 1052-1060

35. Pausas, J.G. et al. (2017) Flammability as an ecological and evolutionary driver. J. Ecol. 105, 289-297

36. Dantas, V.L. and Pausas, J.G. (2013) The lanky and the corky: fire-escape strategiesin savanna woody species. J. Ecol. 101, 1265-1272

37. Pausas, J.G. (2017) Bark thic kness and fire regime: another twist. New Phytol. 213, 13-15

38. Pausas, J.G. (2015) Bark thic kness and fire regime. Funct. Ecol. 29, 315-327

39. Lamont, B.B. etal. (1991) Canopyseed stora ge in woody plants. Bot. Rev. 57, 277-317
Crisp, M.D. et al. (2011) Fla mmable biomes dominated by eucalypts originated at the Cretaceous-Palaeogene boundary. Nat. Commun. 2, 193

41. Kershaw, A. etal. (2002) A history of fire in Austra lia . In Flammable Australia: The Fire Regimes and Biodiversity of a Continent (Bradstock, R.A., ed.), pp. 3-25, Ca mbridge University Press

42. Keeley, J .E. etal. (2011) Fire a sa n evolutionarypressure shaping plant tra its. Trends Plant Sci. 16, 406-411

43. Keith, H. et al. (2010) Estimating carbon camying capacity in natural forest ecosystems across heterogeneous landscapes: add ressing so urce soferror.Glob. Change Biol. 16, 2971-2989

44. Burrows, G.E. (2008) Syncarpia and Tristaniopsis (Myrtaceae) possess specialised fire-resistant epicormic structures. Aust. J. Bot. 56, 254-264

45. Hobbs, R.J . and Mooney, H.A. (1985) Vegetative regrowth following cutting in the shrub Baccharispilularis ssp.consanguinea (DC) CB Wolf. Am. J. Bot. 72, 514-519

46. Burrows, G.E. and Chisnall, LK. (2016) Buds buried in bark: the reason why Quercus suber (cork oak) is an excellent post-fire epic ormic resprouter. Trees 30, 241-254

47. Ward ell-J ohnson, G.W. (2000) Responsesofforesteucalyptsto moderate and high intensity fire in the Tingle Mosaic, southwestem Australia: comparisons between locally endemic and regionally distributed species. Austral Ecol. 25, 409-421

48. Tng, D.Y.P. et al. (2012) Giant eucalypts-globally unique fireadapted rain-forest trees? New Phytol. 196,1001-1014

49. Climent, J. et al. (2004) Fire ada ptationsin the Canary Islands pine (Pinus canariensis). PlantEcol. 171, 185-196

50. Dagit, R. et al. (2002) Post-fire monitoring of coast live oaks (Quercus agrifolia) bumed in the 1993 Old Topanga Fire.In Proceedings of the 5th Symposium on Oak Woodlands: Oaks in California's Changing Landscape. 2001 October 22-25; San Diego, CA (Standiford, R.B., ed.), pp. 243-249, USDepartment of Agriculture

51. Plumb, T.R. (1980) Response of oaksto fire. In Proceedings of the Symposium on the Ecology, Management, and Utilization of California Oaks. 1979 June 26-28; Claremont, CA (Plumb, T. R., ed.), pp. 202-215, USDepartment of Agric ulture 